\title{
Post-natal patterns of plasma androgen-binding activity in Djungarian (Phodopus sungorus) and golden (Mesocricetus auratus) hamsters
}

\author{
A. W. Gustafson, D. A. Damassa, R. D. Pratt and G. G. Kwiecinski \\ Department of Anatomy and Cellular Biology, Tufts University Health Sciences Center, \\ 136 Harrison Avenue, Boston, Massachusetts 02111, USA
}

\begin{abstract}
Summary. The binding of sex steroids to plasma proteins was examined in post-natal Djungarian and golden hamsters. With dihydrotestosterone or testosterone as ligands, steady-state polyacrylamide gel electrophoresis revealed 2 androgen binding components in the plasma of young Djungarian hamsters of both sexes. The fast-moving component exhibited a low affinity and high capacity for androgens and corresponded to albumin in stained gels. In contrast, the slow moving component was a $\beta$-globulin with high affinity $\left(K_{\mathrm{a}}=10^{9} \mathrm{M}^{-1}\right)$ and low capacity for androgens, and was identified as a specific sex steroid-binding protein (SBP; also SHBG). This SBP did not bind oestrogens or corticosteroids and was electrophoretically distinct from corticosteroid-binding globulin (CBG). In addition, this protein did not appear to be of testicular origin because it was present in immature females and in immature males that had been castrated for 8 days. Plasma concentrations of SBP in males as measured by a diethylaminoethyl-cellulose binding assay were low at birth, became significantly elevated shortly thereafter when plasma androgen values were also elevated, and subsequently fell to low levels during puberty. These changes follow the same general pattern that has been described for other mammals, including humans, during this period of reproductive development. Although the significance of elevated SBP concentrations during prepuberty has yet to be determined, it appears that the increased concentrations of high-affinity androgen binding in the plasma of Djungarian hamsters plays a role in the asynchronous pubertal development of the testes and accessory organs which occurs in this species. The post-natal SBP pattern in females was similar to that observed in males. Plasma SBP levels were low or undetectable in adults of both sexes. As previously described for adult golden hamsters, the plasma of post-natal male and female golden hamsters lacked a specific SBP: androgen binding in this species is apparently limited to albumin and CBG.
\end{abstract}

Keywords: SBP/SHBG; CBG; steroid-binding; puberty; Djungarian hamster; golden hamster

\section{Introduction}

Sex steroid hormones in the circulation are transported principally bound to plasma proteins. Testosterone, the predominant circulating androgen in most mammals, is no exception and only a small percentage of this steroid normally exists as unbound (free) hormone (see Dunn et al., 1981). An apparently universal component of androgen binding in mammalian blood is provided by albumin. Although this protein binds testosterone and other steroids non-specifically and with low affinity, its high concentration in the circulation is mainly responsible for its importance in high capacity steroid binding. This protein presumably plays a significant role in androgen transport in all mammals. 
A specific sex steroid-binding protein (SBP; also sex hormone-binding globulin, SHBG), which binds testosterone and certain other sex steroids with high affinity, has also been identified in many species. Besides its role in androgen transport, this protein is considered to exert a significant influence on testosterone distribution, availability, and metabolism (for recent reviews, see Westphal, 1985; Bridges et al., 1986; Forest \& Pugeat, 1986; Pardridge, 1987). In addition, a lesser and variable androgen-binding component in plasma has been identified with the corticosteroidbinding globulin (CBG) fraction (Schiller et al., 1977; Mickelson et al., 1981; Robinson et al., 1985; Gray et al., 1987; Kwiecinski et al., 1987). Although a bona-fide SBP appears to be lacking in some species such as the common laboratory rodents (see Corvol \& Bardin, 1973), SBP and albumin account for the majority of the androgen-binding activity in mammalian plasma. The importance of CBG for androgen binding and steroid action in species lacking SBP remains to be determined.

Concentrations of SBP exhibit marked fluctuations during the important reproductive periods of (1) puberty (Danzo \& Eller, 1975; Horst et al., 1977; Blank et al., 1978; Berger et al., 1980; Gaidano et al., 1980; Gustafson \& Damassa, 1984; Lee et al., 1985; Belgorosky \& Rivarola, 1986; Maruyama et al., 1987), (2) pregnancy (Rivarola et al., 1968; Anderson et al., 1976; Heyns, 1977; Schiller et al., 1978; Uriel et al., 1981), and (3) renewal of seasonal activity (Maurel et al., 1980; Audy et al., 1982; Saboureau et al., 1982; Gustafson \& Damassa, 1985). The significance of these fluctuations remains to be clarified.

Gustafson \& Damassa $(1984,1985)$ have suggested that the recurrent high concentrations of SBP in the male bat are related to the delayed development of androgen target organs which occurs in this species both during puberty and during seasonal reactivation of the reproductive system. One important function of SBP in relation to androgen action in these males, therefore, may be in synchronizing their annual reproductive cycle to that of the female.

In a study on pubertal development of the seasonally reproductive Djungarian hamster, Phodopus sungorus, Hoffmann (1978) reported that the testes of animals raised under long photoperiod were large and fully spermatogenic at 31 days of age. The accessory glands, however, did not attain their maximum size until about 60 days. The possibility that a rodent species might also exhibit a delayed accessory gland development in relation to testicular activity during the pubertal process therefore prompted us to examine the androgen and oestrogen-binding properties of Djungarian hamster plasma during the period from birth through sexual maturity.

In addition, we have examined post-natal androgen-binding activity in the plasma of the golden hamster, Mesocricetus auratus, a laboratory rodent which has been shown to lack a specific SBP in adults (Corvol \& Bardin, 1973; Savu et al., 1977; Gray et al., 1987). In this species, pubertal maturation of the testes and the sex accessory glands is known to be synchronous (Ortiz, 1947).

\section{Materials and Methods}

Animals and tissues. Djungarian hamsters (Phodopus sungorus) were obtained from our breeding colony; golden hamsters (Mesocricetus auratus) were obtained from Charles River Breeding Laboratories (Wilmington, MA, USA). The animals were exposed to a photoperiod of $16 \mathrm{~h}$ light and $8 \mathrm{~h}$ darkness (16L:8D; lights on 05:00-21:00 h). Temperature was maintained at $20 \pm 2^{\circ} \mathrm{C}$. Food (Prolab R-M-H 3000, Agway Inc., Syracuse, NY, USA) and water were provided ad libitum.

Animals were anaesthetized and exsanguinated via cardiac cannulation (Gustafson, 1976). All blood samples were collected in the morning and centrifuged at $13000 \mathrm{~g}$ for $7 \mathrm{~min}$. Plasma was frozen in aliquants and stored at $-20^{\circ} \mathrm{C}$ until assay. Reproductive organs (testis, cauda epididymidis, and accessory glands) were removed, dissected free of extraneous connective tissues, and weighed to the nearest $0.11 \mathrm{mg}$. Testicular and epididymal weights are presented as paired values. The accessory glands were weighed as a complex after removal of the urinary bladder; in animals 5 weeks of age and older, luminal secretions were expressed out of the glands before weight determinations. Immediately after weighing, tissues from selected animals were immersed in Duboscq-Brasil fixative, subsequently embedded in Paraplast Plus (Lancer, Sherwood Medical, St Louis, MO, USA), sectioned, and stained for histological analysis.

Reagents. Radiolabelled steroids were obtained from New England Nuclear (Boston, MA, USA). For steroidbinding analyses and filter assay efficiency determinations, $\left[1,2,4,5,6,7-{ }^{3} \mathrm{H}\right]$ dihydrotestosterone $\left(\left[{ }^{3} \mathrm{H}\right] \mathrm{DHT}\right)$ was 
purified by reversed-phase, Celite column chromatography before use according to the method of Corpechot $e t$ al. (1981). Electrophoresis reagents were obtained from Bio-Rad Laboratories (Richmond, CA, USA) and used without further purification.

Polyacrylamide gel electrophoresis. Steroid binding was identified by means of steady-state analytical polyacrylamide gel electrophoresis (SS-PAGE) according to the method of Ritzen et al. (1974). Gels containing $5 \%$ acrylamide $(\mathrm{w} / \mathrm{v})$ and $0 \cdot 17 \%$ bisacrylamide (w/v) were cast as described previously (Damassa et al., 1982). Plasma samples from male, female, and castrated male hamsters were charcoal-stripped, diluted $(1 / 20$ to $1 / 50)$, incubated with tritiated steroid (DHT), testosterone, oestradiol, cortisol, or corticosterone) and applied to gels containing the same radiolabelled steroid, either alone or in combination with a 100 -fold molar excess of radioinert hormone. For studies conducted under non-steady-state conditions (NSS-PAGE), samples were separated on gels that did not contain steroids.

Electrophoresis was performed at $4^{\circ} \mathrm{C}$ with a constant current of $2 \mathrm{~mA}$ per gel until the bromphenol blue tracking dye had migrated approximately $9 \mathrm{~cm}$. Gels were then removed from the tubes, frozen, cut transversely into $2-\mathrm{mm}$ slices, and analysed for tritium activity by liquid scintillation counting. Gels that did not contain radiolabelled steroids were run in parallel with the tritiated gels and stained with bromcresyl green for the localization of albumin. The mobilities of proteins which bound steroids were calculated as the ratio of their migration in a gel to the migration of the bromphenol blue dye front and expressed as relative mobility $\left(R_{\mathrm{f}}\right)$ values.

Measurement of SBP. The concentrations of SBP in plasma were determined using the DEAE-cellulose filter assay (DEAE-CFA) of Mickelson \& Petra (1974). Samples were diluted 1/33.3 (v/v) with a charcoal solution consisting of $1.25 \mathrm{~g}$ washed Norit A per $100 \mathrm{ml} 10 \mathrm{~mm}$-Tris- $\mathrm{HCl}$ buffer, $\mathrm{pH} 7.4$. The samples were incubated in this solution, with periodic gentle mixing, for $0.5 \mathrm{~h}$ at $25^{\circ} \mathrm{C}$ to remove endogenous steroids. After incubation, the mixture was centrifuged at $4^{\circ} \mathrm{C}$, once at $2000 \mathrm{~g}$ for $10 \mathrm{~min}$ and then twice at $12000 \mathrm{~g}$ for $5 \mathrm{~min}$ each to ensure removal of residual charcoal. This charcoal-treatment procedure removed more than $99 \%$ of endogenous androgens. Aliquants of the charcoal-stripped supernatant were diluted further with $10 \mathrm{~mm}$-Tris-HCl buffer to final dilutions of between $1 / 50$ and $1 / 1000$, and incubated with a saturating concentration of $\left[{ }^{3} \mathrm{H}\right] \mathrm{DHT}(5 \mathrm{nM})$. Replicate samples were prepared with a 100-fold molar excess of radioinert DHT to assess non-specific binding. The samples plus labelled steroid were incubated at $25^{\circ} \mathrm{C}$ for $15 \mathrm{~min}$ and then placed in an ice bath for $30 \mathrm{~min}$. Samples of $100 \mu$ were applied to Whatman (Clifton, NJ, USA) DEAE-cellulose filter disks (DE81) which were mounted in a 10-place filtration apparatus (YEDA Scientific, Rehovot, Israel) maintained at $4^{\circ} \mathrm{C}$. After $2 \mathrm{~min}$, unbound radioactivity was removed from the disks with $10 \times 1.0 \mathrm{ml}$ washes of cold $10 \mathrm{mM}$-Tris- $\mathrm{HCl}$. The washing procedure was carried out by applying gentle vacuum to the filtration apparatus. After filtration, the disks were placed in vials containing $10 \mathrm{ml}$ scintillant and counted as described above. Quench corrections were made for each sample. Concentrations of SBP were calculated from the radioactivity retained by the filter disks after correcting for non-specific binding, assay 'efficiency' (51\%), and plasma dilution. Results are expressed as $\mathrm{nM}(\mathrm{nmol} / \mathrm{l})$ with the assumption of mol:mol stoichiometry of DHT binding (see Rosner \& Smith, 1975). All samples were measured in duplicate with an interassay coefficient of variation of $15.5 \%$.

Measurement of androgens. Plasma androgen concentrations were measured by RIA. Details of the assay have been described previously (Gustafson \& Damassa, 1984, 1985). Values for the samples were determined from the standard curve by linear interpolation following log (standard value)-logit transformation. The $90 \%$ intercept was between 5 and $10 \mathrm{pg} /$ tube. The intra- and interassay variabilities, determined from a plasma pool assayed in duplicate at three different dilutions in each of three assays, were 11.4 and $16.4 \%$, respectively. Water blanks were not different from the 0 -pg testosterone standard. All samples were measured in duplicate.

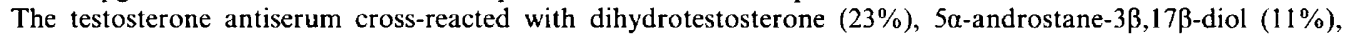
$5 \alpha$-androstane- $3 \alpha, 17 \beta$-diol $(6 \%)$. Cross-reactivity with other steroids was low: androstenedione $(2 \%)$, oestradiol-17 $\beta$ $(0.11 \%)$, progesterone $(0.02 \%)$, and $<0.005 \%$ for oestrone, cortisol and corticosterone. Since the anti-testosterone serum exhibited a limited cross-reactivity with various $5 \alpha$-reduced androgens and plasma extracts were not subjected to chromatographic separation of these androgens, the resultant values were expressed as concentrations of plasma androgens.

Affinity determinations. The constant of association $\left(K_{\mathrm{a}}\right)$ for the binding of DHT to the SBP $\left(K_{\mathrm{a}}: \mathrm{SBP}-\mathrm{DHT}\right)$ of Djungarian hamsters was estimated at $4^{\circ} \mathrm{C}$ using the DEAE-CFA and by SS-PAGE as described above. For all studies, plasma was charcoal-treated and diluted with $10 \mathrm{~mm}$-Tris buffer $(\mathrm{pH} 7 \cdot 4)$ before analysis.

For the determination of $K_{\mathrm{a}}$ :SBP-DHT using the DEAE-CFA, the plasma aliquants were incubated with various amounts of $\left[{ }^{3} \mathrm{H}\right] \mathrm{DHT}$ or with a fixed amount of $\left[{ }^{3} \mathrm{H}\right] \mathrm{DHT}$ and various amounts of radioinert DHT. When equilibrium had been established following incubations at $25^{\circ} \mathrm{C}(15 \mathrm{~min})$ and $4^{\circ} \mathrm{C}(30 \mathrm{~min})$, the bound and unbound steroid was separated. The $K_{\mathrm{a}}$ of SBP for the binding of DHT and the concentration of SBP (DHT-binding sites) in the diluted plasma were determined by utilizing the computer program package, LIGAND, as described by Munson \& Rodbard (1980). Combined analysis was made using the results from three separate experiments in which plasma was diluted $1 / 100,1 / 100$, and $1 / 200$, respectively.

For the determination of $K_{\mathrm{a}}:$ SBP-DHT by SS-PAGE, the procedures of Ritzen et al. (1974) for the binding of a ligand to a protein under steady-state conditions were employed for the calculation of $K_{\mathrm{a}}\left(1 / K_{\mathrm{d}}\right)$. Polyacrylamide gels $(5 \%)$ containing $2 \cdot 27 \mathrm{nM}-\left[{ }^{3} \mathrm{H}\right] \mathrm{DHT}$ were cast as described above. Charcoal-treated plasma was diluted $(1 / 20$ or $1 / 50)$, incubated with $2 \cdot 27-\mathrm{nm}-\left[{ }^{3} \mathrm{H}\right] \mathrm{DHT}$, and subjected to electrophoresis as outlined above. These procedures were conducted using 12 separate electrophoretic runs; only results from gels at steady state $(n=6)$ were used in the calculations. The concentration of SBP in hamster plasma was determined using the DEAE-CFA under the conditions of saturating concentrations of $\left[{ }^{3} \mathrm{H}\right] \mathrm{DHT}$. 
Steroid specificity of SBP. The competitive effects of various steroids on $\left[{ }^{3} \mathrm{H}\right] \mathrm{DHT}$ binding to SBP were tested using the DEAE-CFA. Samples of diluted Djungarian hamster plasma were incubated with radiolabelled DHT and various concentrations of radioinert steroids. The displacement curves for each steroid were linearized with a $\log$-logit transform and the relative binding affinities were calculated by comparing the amount of radioinert steroid required to produce a $50 \%$ reduction of radiolabelled DHT binding (Rodbard, 1973). Binding specificity results are expressed relative to DHT. The amount of radioactivity bound in the absence of competing steroid was considered to be $100 \%$.

Data analysis. Data from sample groups are reported as mean \pm s.e.m. Measurements of SBP, testosterone, reproductive organ weights, and body weights over time during the postnatal period were each subjected to one-way analysis of variance. Comparisons between means of the various age groups were made using Student-NewmanKeuls multiple comparison tests. Differences were regarded as significant when $P$ values were $<0.05$. If appropriate, data were subjected to logarithmic transformation before analysis to stabilize the variance.

\section{Results}

\section{Steroid-binding activity in golden hamster plasma}

Analysis of androgen-binding activity in the plasma of golden hamsters revealed that males and females lacked a specific SBP during the post-natal-period: 14 males and 10 females were examined from birth to 4 weeks of age. With [ $\left.{ }^{3} \mathrm{H}\right] \mathrm{DHT}$ as ligand, SS-PAGE did, however, reveal two peaks of androgen-binding activity (Fig. 1). The slower moving peak (lower relative mobility; gel slice numbers 22-25) was presumed to be due to albumin based upon its relative mobility. The faster moving peak (gel slice numbers 28-30) corresponded to those identified as CBG in previous studies (Corvol \& Bardin, 1973; Gray et al., 1987). Furthermore, a peak with similar mobility was identified when parallel steady-state gels were run with $\left[{ }^{3} \mathrm{H}\right]$ corticosterone as the ligand. NSSPAGE revealed that this component was saturable since the corticosteroid radioactivity was totally displaced by a 100 -fold molar excess of radioinert corticosterone. Using $\left[{ }^{3} \mathrm{H}\right]$ oestradiol as a ligand, no oestrogen-binding activity was observed in postnatal plasma.

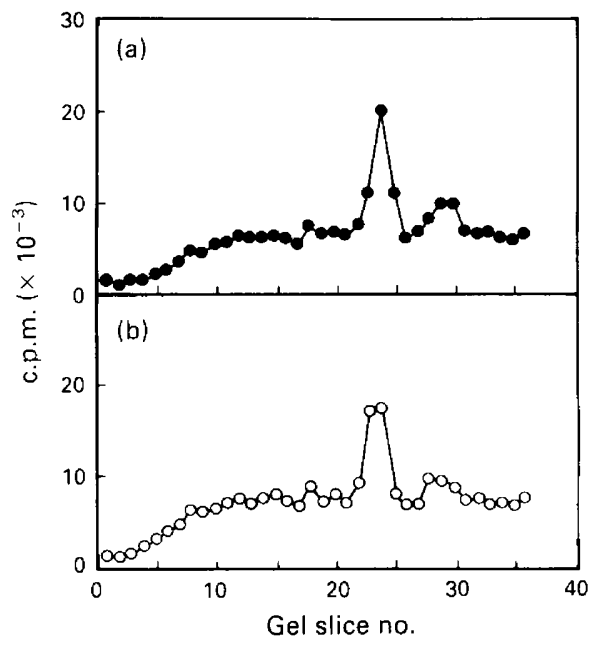

Fig. 1. The binding of $\left[{ }^{3} \mathrm{H}\right] \mathrm{DHT}$ to 4 -week-old male (a) and female (b) golden hamster plasma after fractionation by SS-PAGE at $\mathrm{pH} 8 \cdot 9\left(4^{\circ} \mathrm{C}\right)$.

SS-PAGE demonstrated that the DHT-binding activity of both fractions increased postnatally. Being low at birth, these activities in gels showed a steady increase in the binding of radiolabelled ligands (binding capacity) over the 4-week period that was examined in this study. 
Steroid-binding activity in Djungarian hamster plasma

Identification of a specific SBP. Steady-state electrophoresis of plasma samples from post-natal hamsters in gels containing $\left[{ }^{3} \mathrm{H}\right] \mathrm{DHT}$ resulted in two prominent peaks of androgen-binding activity (Fig. 2a). The fast moving peak (gel slice numbers 25-26) corresponded to albumin in stained gels. The slower migrating peak (gel slice numbers 11-14) was defined as the Djungarian hamster SBP. Electrophoretic studies using non-steady-state conditions revealed that this component was specific and saturable since the peak was totally displaced by a 100-fold molar excess of radioinert DHT, but not by radioinert corticosteroids. The high capacity albumin peak, however, could not be displaced with 100-fold molar excess of unlabelled DHT. NSS-PAGE of plasma incubated with radiolabelled DHT also resulted in maintenance of the SBP peak but disappearance of the albumin peak, suggesting that the slow moving androgen-binding component was of high affinity. This notion was confirmed by affinity determinations (see below).

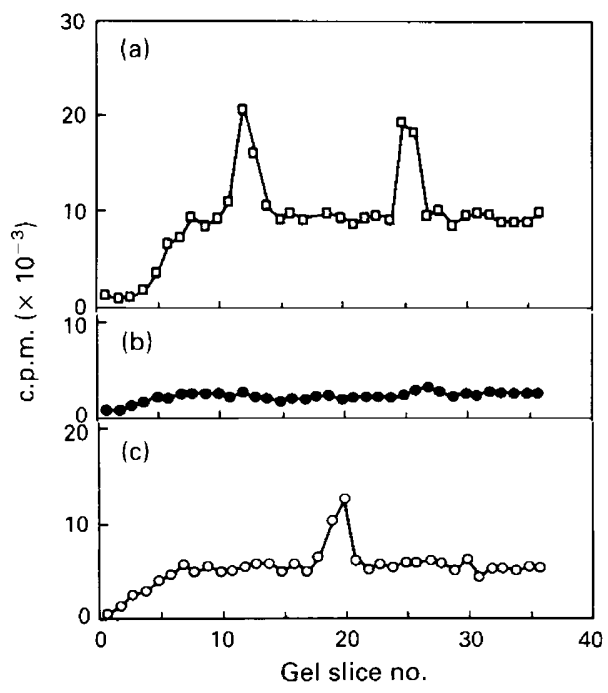

Fig. 2. The binding of $\left[{ }^{3} \mathrm{H}\right] \mathrm{DHT}$ (a) and $\left[{ }^{3} \mathrm{H}\right]$ cortisol (c) but not $\left[{ }^{3} \mathrm{H}\right]$ oestradiol (b) to plasma of post-natal male Djungarian hamsters after fractionation by SS-PAGE.

The SBP also bound testosterone (data not shown) but not oestradiol-17 $\beta$ (Fig. 2b). These binding properties suggested that this protein in the Djungarian hamster binds only androgen.

In addition, SS-PAGE revealed a single corticosteroid-binding component when either $\left[{ }^{3} \mathrm{H}\right]$ cortisol (Fig. 2c) or $\left[{ }^{3} \mathrm{H}\right]$ corticosterone (data not shown) were used as ligands. This component (gel slice numbers 17-20) exhibited a relative mobility that was intermediate to the mobilities of SBP and albumin and appeared to correspond to a corticosteroid-binding globulin (CBG). NSS-PAGE studies revealed that this plasma protein was likewise specific and saturable since the radioactivity of the peak was totally displaced by a 100 -fold molar excess of radioinert corticosteroid, but not by radioinert DHT.

Plasma SBP activity was not only identified in post-natal males but also in the plasma of postnatal females (Fig. 3b). However, in plasma of adult hamsters, this protein was low or undetectable (male: Fig. 3c and Table 2; female: Table 3). This saturable androgen-binding component did not appear to originate from the testis since it was found in the plasma of post-natal females and also was not diminished in post-natal males that had been castrated for 8 days (Fig. 3a). This protein therefore appeared to be distinct from a Sertoli cell androgen-binding protein (ABP). 


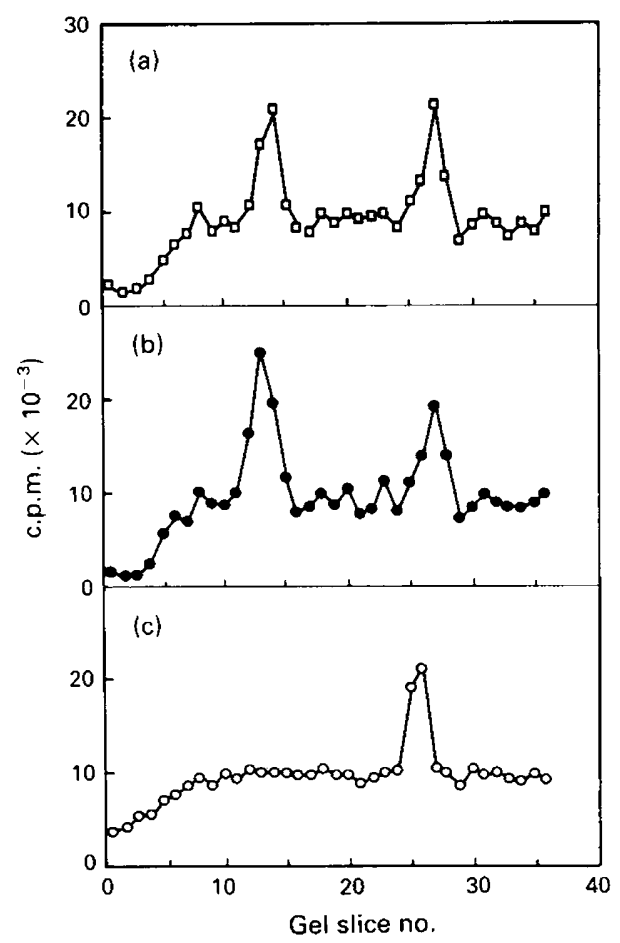

Fig. 3. The binding of $\left[{ }^{3} \mathrm{H}\right] \mathrm{DHT}$ to plasma of castrated post-natal male (a), post-natal female (b), and adult male (c) Djungarian hamsters after fractionation by SS-PAGE.

Affinity determinations for the SBP. The constant of association for the binding of DHT to SBP $\left(K_{\mathrm{a}}:\right.$ SBP-DHT) was determined at $4^{\circ} \mathrm{C}$ by LIGAND analysis and by SS-PAGE. LIGAND analysis of the data obtained from the DEAE-CFA ( $n=39$ determinations) gave a best fit with a 1 site model. The $K_{\mathrm{a}}: \mathrm{SBP}-\mathrm{DHT}$ for this site was $3.0 \pm 1.8 \times 10^{9} \mathrm{M}^{-1}$. Estimation of $K_{\mathrm{a}}: \mathrm{SBP}-\mathrm{DHT}$ using the SS-PAGE method ( $n=6$ determinations) yielded an essentially similar value: $1.4 \pm 0.5 \times 10^{9} \mathrm{M}^{-1}$. The results of both methods indicated that the SBP exhibited a high affinity for DHT.

Specificity of the SBP. The competitive effects of various steroids on DHT binding to the SBP in Djungarian hamster plasma are shown in Table 1 . The results of these studies indicated that the SBP bound DHT and testosterone with a high affinity, but exhibited low relative affinity for the other androgens examined, for the oestrogens tested, and also for progesterone. In addition, the SBP showed negligible relative affinity for cortisol and corticosterone.

\section{Post-natal patterns of plasma SBP and androgen in the Djungarian hamster}

Plasma androgen-binding activity in male Djungarian hamsters exhibited dramatic changes during the post-natal period. The temporal pattern of DHT binding to SBP and albumin in steadystate gels is shown in Fig. 4. Androgen binding attributable to albumin (peaks of higher relative mobility; gel slice numbers 24-27) was low at birth but increased gradually until the 6th post-natal week. At this time, the DHT-binding to albumin appeared to be similar to the activity observed in adult plasma (see Fig. 3). In contrast, androgen binding by SBP (peaks of lower relative mobility; gel slice numbers 10-15) increased markedly between birth and 1 week of age. It remained high through the 3 rd week and then fell between the 4th and 6th post-natal weeks. Likewise, the SBP activity at this time was similar to the activity observed in adult male plasma (see Fig. 3). 
Table 1. Steroid specificity of the plasma sex steroid-binding protein in the Djungarian hamster

\begin{tabular}{lc}
\hline \multicolumn{1}{c}{ Steroid } & $\begin{array}{c}\text { Relative affinity } \\
(\%)\end{array}$ \\
\hline $5 \alpha$-Dihydrotestosterone & 100 \\
Testosterone & 63 \\
$5 \alpha$-Androstane-3 $3,17 \beta$-diol & 10 \\
Oestradiol-17 $\beta$ & $5 \cdot 6$ \\
Oestrone & $2 \cdot 9$ \\
Progesterone & $2 \cdot 7$ \\
Androstenedione & $1 \cdot 4$ \\
$5 \alpha$-Androstane-3 $\alpha, 17 \beta$-diol & $1 \cdot 3$ \\
Cortisol & $0 \cdot 9$ \\
Corticosterone & $0 \cdot 09$ \\
\hline
\end{tabular}

Relative affinity (binding) was defined by the ratio of the amounts of $\left[{ }^{3} \mathrm{H}\right] \mathrm{DHT}$ to competing steroids which resulted in $50 \%$ displacement of the $\left[{ }^{3} \mathrm{H}\right] \mathrm{DHT}$.

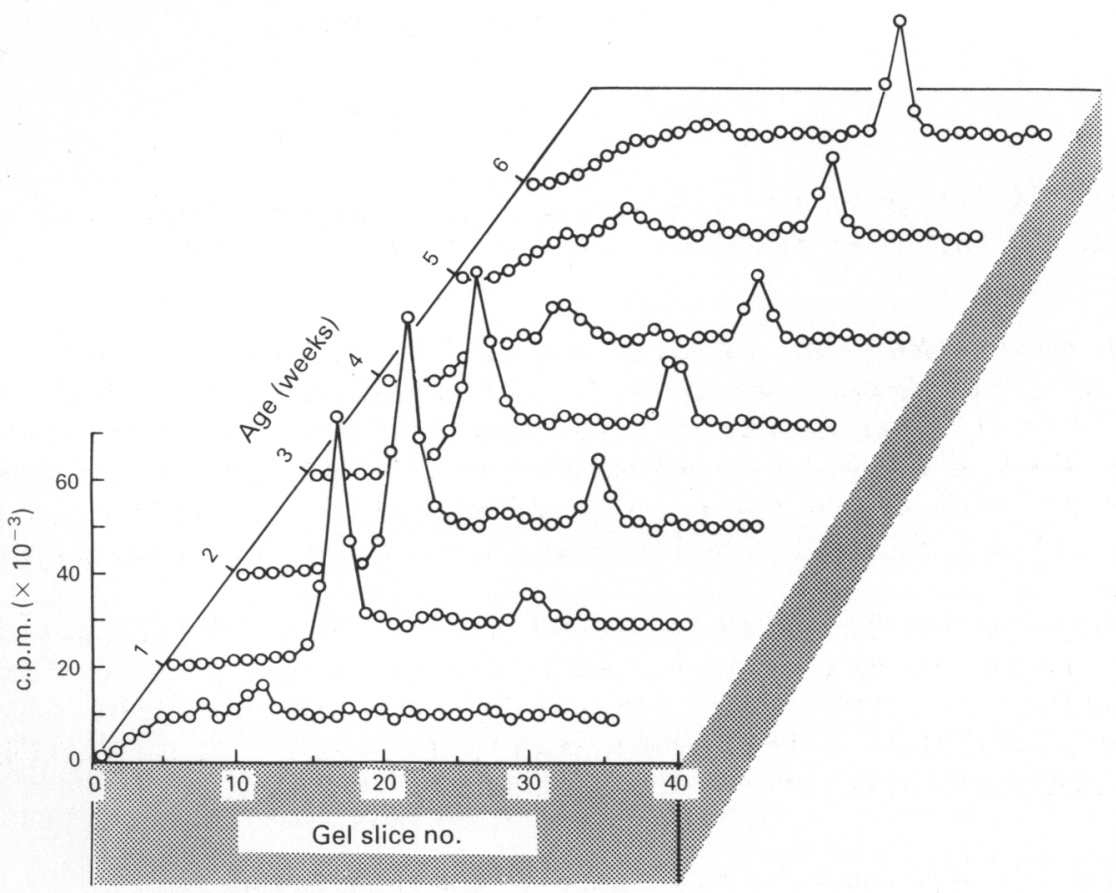

Fig. 4. The binding of $\left[{ }^{3} \mathrm{H}\right] \mathrm{DHT}$ to plasma of male Djungarian hamsters during the first 6 weeks of life after fractionation by SS-PAGE.

When the concentrations of SBP were measured by the DEAE-CFA, the post-natal pattern suggested by the SS-PAGE gels was confirmed (Table 2). Low just before term and after birth, SBP levels increased significantly at 1 day post partum. By 1 week, they had increased more than 10-fold over perinatal values, reaching their maximal levels. These high titres were maintained in the circulation through the 3 rd week. At 4 weeks of age, SBP concentrations decreased significantly and reached low baseline levels characteristic of adult plasma by the 5 th and 6 th post-natal weeks. 
These negligible SBP levels were measured in the circulation of all older animals and appeared to be characteristic of reproductively active adult males.

Total plasma androgen concentrations (Table 2) also exhibited changes from birth to sexual maturity, ranging from 0.5 to $18.4 \mathrm{ng} / \mathrm{ml}$. Although considerable variance was observed and contributed to the few significant differences (see Table 2) afforded by the post-hoc test employed, a general pattern was discerned. In sum androgen concentrations were elevated the week after birth, subsequently were somewhat lower (at least at 4 weeks of age), and appeared to increase in males that were 5 weeks and older. However, the only significant differences which resulted from the Newman-Keuls test were that the 4 week levels were lower than those measured at 1 day and 1 week.

Table 2. Variations in body weight, reproductive organ weights, and plasma androgen and SBP concentrations from birth to adulthood in male Djungarian hamsters

\begin{tabular}{lccccccc}
\hline Age & No. & $\begin{array}{c}\text { Body wt } \\
(\mathrm{g})\end{array}$ & $\begin{array}{c}\text { Testes } \\
(\mathrm{mg})\end{array}$ & $\begin{array}{c}\text { Epididymal } \\
\text { caudae } \\
(\mathrm{mg})\end{array}$ & $\begin{array}{c}\text { Accessory sex } \\
\text { glands } \\
(\mathrm{mg})\end{array}$ & $\begin{array}{c}\text { Androgens } \\
(\mathrm{ng} / \mathrm{ml})\end{array}$ & $\begin{array}{c}\text { SBP } \\
(\mathrm{nM})\end{array}$ \\
\hline Fetus* & 4 & - & - & - & - & - & $23 \pm 9^{\mathrm{a}}$ \\
Birth & 7 & $1 \cdot 6 \pm 0 \cdot 1^{\mathrm{a}}$ & $1 \cdot 4 \pm 0 \cdot 1^{\mathrm{a}}$ & - & $1 \cdot 2 \pm 0 \cdot 1^{\mathrm{a}}$ & $3 \cdot 3 \pm 1 \cdot 0^{\mathrm{ab}}$ & $17 \pm 3^{\mathrm{a}}$ \\
I day & 6 & $1 \cdot 8 \pm 0 \cdot 1^{\mathrm{a}}$ & $1 \cdot 8 \pm 0 \cdot 1^{\mathrm{a}}$ & $0 \cdot 2 \pm 0 \cdot 1^{\mathrm{a}}$ & $1 \cdot 3 \pm 0 \cdot 1^{\mathrm{a}}$ & $5 \cdot 8 \pm 2 \cdot 0^{\mathrm{b}}$ & $89 \pm 12^{\mathrm{bc}}$ \\
7 days & 6 & $5 \cdot 1 \pm 0 \cdot 2^{\mathrm{b}}$ & $10 \cdot 1 \pm 0 \cdot 8^{\mathrm{b}}$ & $1 \cdot 7 \pm 0 \cdot 2^{\mathrm{b}}$ & $5 \cdot 2 \pm 0 \cdot 4^{\mathrm{b}}$ & $5 \cdot 7 \pm 1 \cdot 2^{\mathrm{b}}$ & $243 \pm 29^{\mathrm{d}}$ \\
14 days & 9 & $9 \cdot 8 \pm 0 \cdot 4^{\mathrm{c}}$ & $56 \cdot 6 \pm 4 \cdot 4^{\mathrm{c}}$ & $3 \cdot 9 \pm 0 \cdot 2^{\mathrm{c}}$ & $11 \cdot 9 \pm 0 \cdot 4^{\mathrm{c}}$ & $1 \cdot 5 \pm 0 \cdot 3^{\mathrm{ab}}$ & $196 \pm 27^{\mathrm{d}}$ \\
21 days & 11 & $16 \cdot 8 \pm 0 \cdot 4^{\mathrm{d}}$ & $185 \pm 16^{\mathrm{d}}$ & $7 \cdot 5 \pm 0 \cdot 6^{\mathrm{d}}$ & $21 \cdot 1 \pm 1 \cdot 4^{\mathrm{d}}$ & $2 \cdot 0 \pm 0 \cdot 5^{\mathrm{ab}}$ & $134 \pm 11^{\text {cd }}$ \\
28 days & 8 & $21 \cdot 7 \pm 1 \cdot 1^{\mathrm{e}}$ & $369 \pm 44^{\mathrm{e}}$ & $11 \cdot 0 \pm 1 \cdot 3^{\mathrm{e}}$ & $41 \cdot 7 \pm 5 \cdot 3^{\mathrm{e}}$ & $0 \cdot 8 \pm 0 \cdot 2^{\mathrm{a}}$ & $58 \pm 11^{\mathrm{b}}$ \\
35 days & 8 & $30 \cdot 1 \pm 0 \cdot 9^{\mathrm{f}}$ & $537 \pm 47^{\mathrm{f}}$ & $22 \cdot 0 \pm 1 \cdot 7^{\mathrm{f}}$ & $85 \cdot 8 \pm 6 \cdot 5^{\mathrm{f}}$ & $2 \cdot 6 \pm 0 \cdot 6^{\mathrm{ab}}$ & $28 \pm 8^{\mathrm{a}}$ \\
42 days & 7 & $31 \cdot 6 \pm 1 \cdot 2^{\mathrm{f}}$ & $723 \pm 14^{\mathrm{g}}$ & $38 \cdot 9 \pm 2 \cdot 4^{\mathrm{g}}$ & $134 \pm 12^{\mathrm{g}}$ & $6 \cdot 3 \pm 2 \cdot 7^{\mathrm{ab}}$ & $19 \pm 4^{\mathrm{a}}$ \\
Adult & 18 & $41 \cdot 9 \pm 1 \cdot 4^{\mathrm{g}}$ & $827 \pm 25^{\mathrm{g}}$ & $122 \pm 5^{\mathrm{b}}$ & $625 \pm 30^{\mathrm{h}}$ & $1 \cdot 8 \pm 0 \cdot 9^{\mathrm{ab}}$ & $9 \pm 2^{\mathrm{a}}$ \\
F (ANOVA) & & 373 & 624 & 437 & 688 & $2 \cdot 99$ & $37 \cdot 7$ \\
$P$ & & $<0 \cdot 001$ & $<0 \cdot 001$ & $<0 \cdot 001$ & $<0 \cdot 001$ & $<0 \cdot 01$ & $<0 \cdot 001$ \\
\hline
\end{tabular}

Values are mean \pm s.e.m.

Means with a superscript in common are not significantly different from one another; means with no superscripts in common are significantly different (Student-Newman-Keuls test). For those time periods in which the sample size varied according to parameter measured, the value given is the mean for that age group.

*At or near term fetuses; crown-rump length $=18-20 \mathrm{~mm}$.

Changes in plasma SBP concentrations were also observed in female Djungarian hamsters during the post-natal period (Table 3). The pattern measured in females was essentially similar to that described for the males. In addition, low levels of SBP were measured in 3 pregnant females, 1 in early pregnancy and 2 near term.

\section{Post-natal changes in reproductive organs of Djungarian hamsters}

Developmental increases in the male reproductive organ weights of the Djungarian hamster from birth through sexual maturation, as well as the pattern of body weight increases to adult levels, are shown in Table 2. Testicular weights were low at birth, but significantly increased by the end of the first week of life. The testes then exhibited rapid and significant increases in their weights during each subsequent week up to the 6th post-natal week. At this time these organs attained a size which was not significantly different from that of adults.

Histological examination of the testes in newborn animals revealed seminiferous cords filled with large and numerous spermatogonial cells. These cells occupied more central locations in the 
Table 3. Variations in body weight and plasma SBP concentrations from birth through adulthood in female Djungarian hamsters

\begin{tabular}{lccc}
\hline \multicolumn{1}{c}{ Age } & No. & $\begin{array}{c}\text { Body wt } \\
(\mathrm{g})\end{array}$ & $\begin{array}{c}\text { SBP } \\
(\mathrm{nM})\end{array}$ \\
\hline Fetus* & 7 & - & $7 \pm 1^{\mathrm{a}}$ \\
Birth & 8 & $1 \cdot 5 \pm 0 \cdot 1^{\mathrm{a}}$ & $31 \pm 7^{\mathrm{b}}$ \\
$\quad$ 1 day & 4 & $1 \cdot 7 \pm 0 \cdot 1^{\mathrm{a}}$ & $59 \pm 17^{\mathrm{bc}}$ \\
7 days & 9 & $5 \cdot 3 \pm 0 \cdot 2^{\mathrm{b}}$ & $133 \pm 17^{\mathrm{d}}$ \\
14 days & 8 & $9 \cdot 1 \pm 0 \cdot 5^{\mathrm{c}}$ & $217 \pm 33^{\mathrm{d}}$ \\
21 days & 6 & $15 \cdot 1 \pm 0 \cdot 4^{\mathrm{d}}$ & $124 \pm 25^{\mathrm{d}}$ \\
28 days & 9 & $20 \cdot 2 \pm 0 \cdot 4^{\mathrm{e}}$ & $64 \pm 9^{\mathrm{c}}$ \\
35 days & 4 & $23 \cdot 9 \pm 1 \cdot 4^{\mathrm{f}}$ & $44 \pm 17^{\mathrm{bc}}$ \\
42 days & 9 & $26 \cdot 2 \pm 0 \cdot 9^{\mathrm{f}}$ & $14 \pm 3^{\mathrm{a}}$ \\
84 days & 6 & $37 \cdot 9 \pm 0 \cdot 7^{\mathrm{g}}$ & $<6^{\mathrm{a}}$ \\
F (ANOVA) & & 373 & $37 \cdot 7$ \\
$P$ & & $<0 \cdot 001$ & $<0 \cdot 001$ \\
\hline
\end{tabular}

Values are mean \pm s.e.m.

Means with a superscript in common are not significantly different from one another; means with no superscripts in common are significantly different (Student-Newman-Keuls test).

*At or near term fetuses; crown-rump length $=17$ $21 \mathrm{~mm}$.

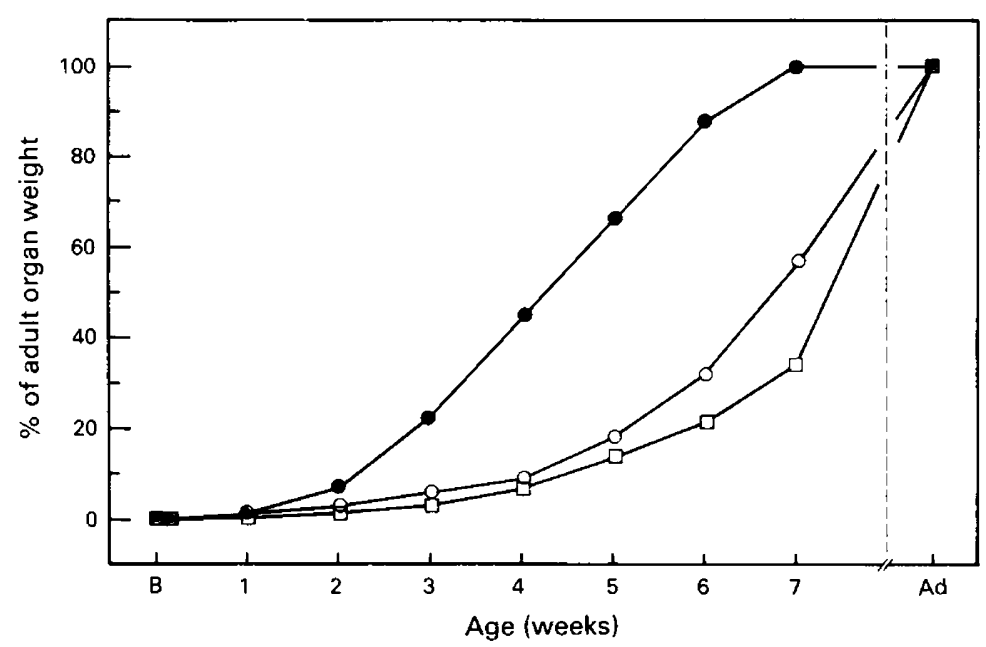

Fig. 5. Maturational increases in weights ( $\%$ of adult organ weights) of the paired testes $(--)$, paired cauda epididymidis (-O-), and accessory sex glands (- -- ) from birth (B) to adulthood (Ad) in the Djungarian hamster. The accessory organs exhibited a marked delay in their pubertal development in relation to that of the testes.

cords while the presumptive Sertoli cells were located more peripherally. At 1 week, the cords appeared to contain relatively fewer spermatogonial cells, which were now mostly peripheral in placement, and many widely distributed Sertoli elements. By the 2 nd week, testicular volume had markedly increased and numerous primary spermatocytes were present in many of the seminiferous 
cords. This morphological condition indicated that spermatogenesis had started and it signalled the onset of the pubertal process. At 3 weeks of age, the seminiferous tubules contained lumina and spermatogenesis had advanced to meiosis throughout. During the 4th week, the lumina were enlarged and spermiogenesis had begun in numerous tubules. In 5-week-old males, spermiogenesis was observed in most tubules and at 6 weeks of age the testes were fully involved in all stages of spermatogenic activity. The histological appearance of these organs was now indistinguishable from that of adult gonads.

The weights of the accessory reproductive organs (cauda epididymidis and accessory glands) also appeared to increase beginning at 1 week of age (see Table 2). Significant increases occurred during each of the first 6 post-natal weeks that were examined in this study. However, these increases were not as rapid as those of the testes (Fig. 5). Graphed as percentage of the corresponding organ weights in 12-week or older adult males, the testes exhibited a markedly accelerated increase in weight as compared to the accessory organs. For example, at 5 weeks of age, the testes had attained more than $65 \%$ of their adult weight, whereas the accessory organs at this same period had reached less than $20 \%$ of their adult weight. The end result was that the testes achieved maximal adult weight earlier than the accessory organs (see Fig. 5). Spermatozoa were not observed in the accessory structures until the 6th post-natal week.

\section{Discussion}

A specific sex steroid-binding protein has been identified in the circulation of many mammals (see Westphal, 1985, for references). Nevertheless, a number of investigations have found this protein to be lacking or undetectable in the plasma of common laboratory rodents such as rats, mice, and golden hamsters (Lea \& Stoa, 1972; Corvol \& Bardin, 1973; Stupnicki \& Bartke, 1976; Renoir et al., 1980; Tenniswood et al., 1982). In the present study, however, a specific SBP has been identified in the Djungarian hamster. Although this protein was low or undetectable in the blood of adult reproductively active animals, it was clearly discernible and readily measurable in both young males and females when plasma was fractionated on polyacrylamide gels or analysed by the DEAE-CFA. In contrast, SBP was not observed in the plasma of post-natal golden hamsters. Therefore, based upon the androgen-binding criteria in this study, as well as in previous examinations of plasma from adults of this species (Corvol \& Bardin, 1973; Savu et al., 1977; Gray et al., 1987), it appears that the golden hamster lacks a specific SBP from birth through reproductive maturity.

The Djungarian hamster SBP exhibited high affinity and low capacity for testosterone and DHT, but was not found to bind oestrogens. In this regard, the hamster SBP is similar to those proteins identified in most other mammals but unlike the analogous proteins observed in primates and bats which possess both androgen- and oestrogen-binding properties (e.g. Renoir et al., 1980; Damassa et al., 1982). The electrophoretic studies which indicated that the SBP of the Djungarian hamster was present in post-natal females and in post-natal males castrated for 8 days, as well as the measurements of elevated values in both sexes in the $200 \mathrm{nM}$ range, support the conclusion that this binding activity was due to a bona-fide SBP-type molecule and not to an ABP-like protein of testicular (Sertoli cell) origin. Furthermore, this protein was distinct from CBG. In fact, specific corticosteroid-binding activity was observed in Phodopus plasma. This activity exhibited a mobility in polyacryamide gels that was intermediate to the mobilities of SBP and albumin. This property has been observed for many other mammals (Corvol \& Bardin, 1973; Kwiecinski et al., 1987) and is consistent with CBG being an alpha-globulin in those species.

In golden hamster plasma, on the other hand, corticosteroid-binding activity has been reported to have a higher relative mobility than albumin in gels (Corvol \& Bardin, 1973; Gray et al., 1987). In this species, the CBG activity also has been found to bind androgens. Indeed, Gray et al. (1987) used the androgen-binding properties of golden hamster CBG to develop a protocol for the purification of this protein from pregnancy serum. In the present study, both of these properties, the 
mobility and androgen-binding activity of golden hamster CBG, were observed in the plasma of post-natal animals.

One of the physiologically important periods in reproductive life when SBP levels experience extreme fluctuations takes place during pubertal development and the prepubertal interval which precedes it. In humans in which this protein has been extensively studied, SBP levels undergo marked fluctuations in males during the time between birth and sexual maturity: after parturition, plasma concentrations of SBP increase rapidly during the first few weeks of life; elevated SBP concentrations are subsequently maintained until puberty when they begin to fall, reaching lower adult levels during sexual maturation (for references see Anderson, 1974; Heyns, 1977; Westphal, 1985; Forest et al., 1986). In the few other mammalian species in which SBP concentrations have been measured during this period, the pattern of SBP activity appears to be similar to that observed in human males. For example, in macaque monkeys, plasma SBP concentrations increased immediately after birth and then fell to lower adult levels during puberty (Snipes et al., 1969; Gauthier-Wright et al., 1973; Anderson et al., 1976). A similar pattern was observed in the bat (Gustafson \& Damassa, 1984). In addition, higher concentrations of SBP in immature male plasma than in adult plasma have been measured in chimpanzees (McCormack, 1971), dogs (Tabei et al., 1978), bulls (Thibier \& Martin, 1975), and rabbits (Hansson et al., 1974; Danzo \& Eller, 1975; Corre et al., 1978; Berger et al., 1980). Thus, a marked decline in plasma SBP activity from early post-natal life to sexual maturity appears to be a pattern that is common to many mammalian species. The significance of these changes, however, has not been determined.

The results of the present study indicate that the fluctuations in plasma SBP concentrations in the Djungarian hamster during the post-natal period are like those that have been described previously in other male mammals from birth to sexual maturity. Low at birth, plasma concentrations of this protein were increased by $I$ day of age and reached maximal values by 1 week of age. Shortly after the pubertal process had started, SBP concentrations began to fall and were significantly reduced by the 4 th post-natal week when spermiogenesis had been initiated. When spermatozoa were observed in the excurrent ducts during the 6th post-natal week, SBP titres had already reached low baseline levels which were maintained in spermatogenically active adult males.

Although the precise function of SBP in relation to testosterone action at various androgen target organs is still open to question, there is ample evidence in specific instances to indicate that the fraction of androgen bound to SBP with high affinity is not available for physiological activity (e.g. Vermeulen et al., 1969; Vermeulen \& Verdonck, 1972; Vermeulen \& Ando, 1979). Thus, if SBP values are markedly elevated, the unbound and albumin-bound fractions of testosterone are reduced and the accessory organs do not become stimulated (Gustafson \& Damassa, 1985, 1987). In the present study, the delay of accessory organ stimulation in the presence of high concentrations of SBP suggests a similar phenomenon in the Djungarian hamster. Both the cauda epididymidis and the accessory glands exhibited an obvious delay in their pubertal development. Although the patterns of delay were similar for both, the glands appeared to be more delayed beginning at the 6th week. This divergence (see Fig. 5) may be related to the appearance of spermatozoa in the epididymides that was observed at this time. Since no attempt was made to remove these cells from the cauda before weight determinations, it is possible that the concomitant increase in gamete mass could account for the more rapid weight gain of the cauda. Nevertheless, increases in accessory organ development with slopes that were similar to testicular development did not occur until SBP levels had dropped to baseline.

Despite the few significantly different androgen concentrations during the post-natal period, the pattern determined in this sudy is in good agreement with that reported previously by Yellon \& Goldman (1984). This pattern emphasizes that, even though androgen values may be at their highest levels (from 1-7 days of age), little or no accessory gland stimulation occurred in the presence of the highest SBP concentrations.

A post-natal pattern of SBP activity that was similar to the male pattern was observed in female Djungarian hamsters which also resulted in baseline values in adults. The significance of this 
pattern in females, however, remains unknown. An interesting finding was the apparent maintenance of low SBP values in pregnant animals. This result is in apparent contrast to elevated SBP concentrations measured during pregnancy in other species that possess this protein. Since only a limited number of Djungarian hamster females were examined in this study and no attempt was made to assay this protein at all stages of pregnancy, further examinations are required.

Since the Djungarian hamster is a seasonally reproductive species when housed under naturally changing photoperiods (Hoffmann, 1981), it remains to be shown whether adults of this species exhibit changes in SBP during the normal course of seasonal change, especially during the renewal phase. If SBP should increase at this time in a fashion that is similar to the post-natal pattern, it will also be of interest to determine whether testicular and accessory organ renewal are out of phase as they are during the post-natal period.

We thank Evie Gustafson and Grace Gagin for expert technical assistance. This work was supported in part by PHS Grant HD-16535 and NSF Grant DCB-8718053.

\section{References}

Anderson, D.C. (1974) Sex-hormone-binding globulin. Clin. Endocrinol. 3, 6996.

Anderson, D.C., Lasley, B.L., Fisher, R.A., Shepherd, J.H., Newman, L. \& Hendrickx, A.G. (1976) Transplacental gradients of sex-hormone-binding globulin in human and simian pregnancy. Clin. Endocrinol. 5, $657-669$.

Audy, M.C., Martin, B., Charron, G. \& Bonnin, M. (1982) Steroid-binding proteins and testosterone level in the badger plasma during the annual cycle. Gen. comp. Endocrinol. 48, 239-246.

Belgorosky, A. \& Rivarola, M.A. (1986) Progressive decrease in serum sex hormone-binding globulin from infancy to late prepuberty in boys. J. clin. Endocr. Metab. 63, 510-512.

Berger, M., Corre, M., Jean-Faucher, C., De Turkheim, M., Veyssiere, G. \& Jean, C. (1980) Age related changes in percent binding of testosterone and dihydrotestosterone and unbound testosterone and dihydrotestosterone in rabbit plasma. J. Steroid Biochem. 13, 423-439.

Blank, B., Attanasio, A., Rager, K. \& Gupta, D. (1978) Determination of serum sex hormone binding globulin (SHBG) in preadolescent and adolescent boys. $J$. Steroid Biochem. 9, 121-125.

Bridges, C.D.B., Peters, T., Smith, J.E., Goodman, D.S., Fong, S.-L., Griswold, M.D. \& Musto, N.A. (1986) Biosynthesis and secretion of transport hormones: Interstitial and serum retinol-binding proteins, transthyretin, transferrin, serum albumin, and extracellular sex steroid-binding proteins. Fedn Proc. Fedn Am. Socs ext. Biol. 45, 2291-2303.

Corpechot, C., Baulieu, E.E. \& Robel, P. (1981) Testosterone, dihydrotestosterone and androstanediols in plasma, testes and prostates of rats during development. Acta endocr., Copenh. 96, 127-135.

Corre, M., Berger, M., Jean-Faucher, C., De Turkheim, M., Veyssiere, G. \& Jean, C. (1978) Liaison de la testosterone et de la dihydrotestosterone aux proteines plasmatiques chex le Lapin dans differentes conditions physiologiques. C. r. Séanc. Soc. Biol. 172, 1119-1126.
Corvol, P. \& Bardin, C.W. (1973) Species distribution of testosterone-binding globulin. Biol. Reprod. 8, 277-282.

Damassa, D.A., Gustafson, A.W. \& King, J.C. (1982) Identification of a specific binding protein for sex steroids in the plasma of the male little brown bat, Myotis lucifugus lucifugus. Gen. comp. Endocrinol. 47, 288-294.

Danzo, B.J. \& Eller, B.C. (1975) Steroid-binding proteins in rabbit plasma: Separation of testosterone-binding globulin (TeBG) from corticosteroid-binding globulin (CBG), preliminary characterization of TeBG, and changes in TeBG concentration during sexual maturation. Molec. cell. Endocrinol. 2, 351-368.

Dunn, J.F., Nisula, B.C. \& Rodbard, D. (1981) Transport of steroid hormones: Binding of 21 endogenous steroids to both testosterone-binding globulin and corticosteroid-binding globulin in human plasma. $J$. clin. Endocr, Metab. 53, 58-68.

Forest, M.G. \& Pugeat, M. (Eds) (1986) Binding Proteins of Steroid Hormones. John Libbey Eurotext, London.

Forest, M.G., Bonneton, A., Lecoq, A., Brebant, C. \& Pugeat, M. (1986) Ontogenese de la proteine de liaison des hormones sexuelles (SBP) et de la transcortine (CBG) chez les primates: variations physiologiques et etude dans differents milieux biologiques. In Binding Proteins of Steroid Hormones, pp. 263-291. Eds M. G. Forest \& M. Pugeat. John Libbey Eurotext, London.

Gaidano, G., Berta, L., Rovero, E., Valenzano, C. \& Rosatti, P. (1980) Dynamics of the binding capacity of plasma sex hormone binding globulin (SHBG) for testosterone and dihydrotestosterone during puberty. Clin. Chim. Acta. 100, 91-97.

Gauthier-Wright, F., Baudot, N. \& Mauvais-Jarvis, P. (1973) Testosterone-binding globulin in stump-tailed macaque monkeys (Macaca speciosa). Endocrinology 93, $1277-1286$.

Gray, G.O., Rundle, S. \& Leavitt, W.W. (1987) Purification and partial characterization of a corticosteroidbinding globulin from hamster serum. Biochim. Biophys. Acta 926, 40-53. 
Gustafson, A.W. (1976) An improved method for the collection of plasma in small mammals. Lab. Anim. Sci. 26, 97-98

Gustafson, A.W. \& Damassa, D.A. (1984) Perinatal and postnatal patterns of plasma sex steroid-binding protein and testosterone in relation to puberty in the male little brown bat. Endocrinology 115, 2347-2354.

Gustafson, A.W. \& Damassa, D.A. (1985) Annual variations in plasma sex steroid-binding protein and testosterone concentrations in the adult male little brown bat: Relation to the asynchronous recrudescence of the testis and accessory reproductive organs. Biol. Reprod. 33, 1126-1137.

Gustafson, A.W. \& Damassa, D.A. (1987) Binding of sex steroids to plasma proteins: relation to androgen resistance and asynchronous reproductive patterns in hibernating bats. In Recent Advances in the Study of Bats, pp. 441-458. Eds M. B. Fenton, P. Racey \& J. M. V. Rayner. Cambridge University Press, Cambridge.

Hansson, V., Ritzen, E.M., Weddington, S.C., McLean, W.S., Tindall, D.J., Nayfeh, S.N. \& French, F.S. (1974) Preliminary characterization of a binding protein for androgen in rabbit serum. Comparison with the testosterone-binding globulin (TeBG) in human serum. Endocrinology 95, 690-700.

Heyns, W. (1977) The steroid-binding B-globulin of human plasma. Adv. Steroid Biochem. Pharmacol. 6, $59-79$.

Hofimann, K. (1978) Effects of short photoperiods on puberty, growth and moult in the Djungarian hamster (Phodopus sungorus). J. Reprod. Fert. 54, 2935.

Hoffmann, K. (1981) The role of the pineal gland in the photoperiodic control of seasonal cycles in hamsters. In Biological Clocks in Seasonal Reproductive Cycles, pp. 237-250. Eds B. K. \& D. E. Follett. Wright \& Sons, Bristol.

Horst, H.-J., Bartsch, W. \& Dirksen-Thedens, I. (1977) Plasma testosterone, sex hormone binding globulin binding capacity and per cent binding of testosterone and 5a-dihydrotestosterone in prepubertal, pubertal and adult males. J. clin. Endocr. Metab. 45, 522-527.

Kwiecinski, G.G., Damassa, D.A., Gustafson, A.W. \& Armao, M.E. (1987) Plasma sex steroid binding in Chiroptera. Biol. Reprod. 36, 628-635.

Lea, O.A. \& Stoa, K.F. (1972) The binding of testosterone to different serum proteins: a comparative study. $J$. Steroid Biochem. 3, 409-419.

Lee, I.R., Lawder, L.E., Townend, D.C., Wetherall, J.D. \& Hahnel, R. (1985) Plasma sex hormone binding globulin concentration and binding capacity in children before and during puberty. Acta endocr., Copenh. 109, 276-280.

Maurel, D., Laurent, A.-M., Daniel, J.-Y. \& Boissin, J. (1980) Etude de la capacite de liaison de la proteine plasmatique liant la testosterone chez deux Mammiferes sauvages a activite testiculaire cyclique, le Renard et le Blaireau. C. r. hebd. Séanc. Acad. Sci., Paris D 291, 693-696.

Maruyama, Y., Aoki, N., Suzuki, Y., Ohno, Y., Imamura, M., Saika, T., Sinohara, H. \& Yamamoto, T. (1987) Sex-steroid-binding plasma protein (SBP), testosterone, oestradiol and dehydroepiandrosterone
(DHEA) in prepuberty and puberty. Acta endocr., Copenh. 114, 60-67.

McCormack, S.A. (1971) Plasma testosterone concentration and binding in the chimpanzee; effect of age. Endocrinology 89, 1171-1177.

Mickelson, K.E. \& Petra, P.H. (1974) A filter assay for the sex steroid binding protein (SBP) of human serum. FEBS Lett. 44, 34-38.

Mickelson, K.E., Forsthoefel, J. \& Westphal, U. (1981) Steroid-protein interactions. Human corticosteroid binding globulin: Some physicochemical properties and binding specificity. Biochemistry, N.Y. 20, $6211-6218$

Munson, P.J. \& Rodbard, D. (1980) LIGAND: A versatile computerized approach for characterization of ligand-binding systems. Analyt. Biochem. 107, 220-239.

Ortiz, E. (1947) The postnatal development of the reproductive system of the golden hamster (Cricetus auratus) and its reactivity to hormones. Physiol. Zool. 20, 45-66.

Pardridge, W.M. (1987) Plasma protein-mediated transport of steroid and thyroid hormones. Am. J. Physiol. 252, E157-El64.

Renoir, J.-M., Mercier-Bodard, C. \& Baulieu, E.-E. (1980) Hormonal and immunological aspects of the phylogeny of sex steroid binding plasma protein. Proc. natn. Acad. Sci. USA 77, 4578-4582.

Ritzen, E.M., French, F.S., Weddington, S.C., Nayfeh, S.N. \& Hansson, V. (1974) Steroid binding in polyacrylamide gels. Quantitation at steady state conditions. J. biol. Chem. 249, 6597-6604.

Rivarola, M.A., Forest, M.G. \& Migeon, C.J. (1968) Testosterone, androstenedione and dehydroepiandrosterone in plasma during pregnancy and at delivery: Concentration and protein binding. J. clin. Endocr. Metab. 28, 34-40.

Robinson, P.A., Hawkey, C. \& Hammond, G.L. (1985) A phylogenetic study of the structural and functional characteristics of corticosteroid binding globulin in primates. J. Endocr. 104, 251-257.

Rodbard, D. (1973) Mathematics of hormone-receptor interaction. I. Basic principles. In Receptors for Reproductive Hormones, pp. 289-326. Eds B. W. O'Malley \& A. R. Means. Plenum Press, New York.

Rosner, W. \& Smith, R.N. (1975) Isolation and characterization of the testosterone-estradiol-binding globulin from human plasma. Use of a novel affinity column. Biochemistry, N.Y. 14, 4813-4820.

Saboureau, M., Laurent, A.-M. \& Boissin, J. (1982) Plasma testosterone binding protein capacity in relation to the annual testicular cycle in a hibernating mammal, the hedgehog (Erinaceus europaeus L.). Gen. comp. Endocrinol. 47, 59-63.

Savu, L., Nunez, E.A. \& Jayle, M.F. (1977) High affinity testosterone, corticosterone and progesterone binding activities in pregnant hamster serum. Endocrinology 101, 369-377.

Schiller, H.S., Langley, J.W. \& Petra, P.H. (1977) Corticosteroid binding protein in the plasma of Macaca nemestrina. J. Steroid Biochem. 8, 647-653.

Schiller, H.S., Holm, R.A. \& Sackett, G.P. (1978) Alterations in steroid binding plasma protein in Macaca nemestrina during pregnancy. Am. J. Physiol. 234, E489-E493. 
Snipes, C.A., Forest, M.G. \& Migeon, C.J. (1969) Plasma androgen concentrations in several species of old and new world monkeys. Endocrinology 85, 941-945.

Stupnicki, R. \& Bartke, A. (1976) Binding of testosterone in mouse plasma. Endokrinologie 68, 150-154.

Tabei, T., Mickelson, K.E., Neuhaus, S. \& Petra, P.H. (1978) Sex steroid binding protein (SBP) in dog plasma. J. Steroid Biochem. 9, 983-988.

Tenniswood, M., Abrahams, P., Winterton, V., Bird, C.E. \& Clark, A.F. (1982) Binding of testosterone, $5 \alpha$ dihydrotestosterone and $5 \alpha$-androstane $(3 \alpha-$ and $3 \beta-$ ), $17 \beta$-diols to serum proteins in the rat. J. Steroid Biochem. 16, 617-620.

Thibier, M. \& Martin, B. (1975) Relation entre les proteines de liaison de la testosterone et les concentrations plasmatiques de testosterone et de $\mathrm{LH}$ chez le jeune taurillon. C. r. hebd. Séanc. Acad. Sci., Paris D 281, 827-830.

Uriel, J., Dupiers, M., Rimbaut, C. \& Buffe, D. (1981) Maternal serum levels of sex steroid-binding protein during pregnancy. Br. J. Obstet. Gynaecol. 88, 1229-1232.

Vermeulen, A. \& Ando, S. (1979) Metabolic clearance rate and interconversion of androgen and the influence of the free androgen fraction. J. clin. Endocr. Metab. 48, 320-326.

Vermeulen, A. \& Verdonck, L. (1972) Some studies on the biological significance of free testosterone. J. Steroid Biochem. 3, 421-426.

Vermeulen, A., Verdonck, M., van der Straeten, M. \& Orie, N. (1969) Capacity of the testosterone-binding globulin in human plasma and influence of specific binding of testosterone on its metabolic clearance rate. J. clin. Endocr. Metab. 29, 1470-1480.

Westphal, U. (1985) Steroid-Protein Interactions II. Springer-Verlag, Berlin.

Yellon, S.M. \& Goldman, B.D. (1984) Photoperiod control of reproductive development in the male Djungarian hamster (Phodopus sungorus). Endocrin$\operatorname{ology} 114,664-670$.

Received 5 July 1988 